\title{
The Performance of Language Politeness in Directive and Expressive Speech Acts from West Sumatra's Female DPRD Members on Social Media
}

\author{
Novia Juita ${ }^{1, *}$ Ermanto $^{1}$ \\ ${ }^{1}$ Universitas Negeri Padang Jl. Prof. Dr. Hamka Padang. 25131. Indonesia, \\ *Corresponding author. Email: noviajuita@fbs.unp.ac.id
}

\begin{abstract}
This article was written to explain the politeness of language expressed by women political figures, especially members of the West Sumatra legislative (DPRD) on social media. In this paper, the discussion is limited to (1) the functions of directive and expressive speech acts, (2) the principle of politeness found in the two types of speech acts. The data of this research are in the form of utterances published by the DPRD members on their social media accounts. The data were obtained by documenting the speech of women politicians in their social media accounts (Facebook, Twitter, Instagram) and collecting it in a database. Furthermore, the data that was already in the form of documents (speeches) were analyzed qualitatively with a content analysis design based on pragmatic theory, specifically the theory of speech acts and politeness. Furthermore, the data that was already in the form of documents (speeches) were analyzed qualitatively with a content analysis design based on pragmatic theory, specifically the theory of speech acts and politeness. The results are as follows. First, in directive speech acts there are three functions including inviting/ suggesting, begging, and reminding, whereas in expressive speech acts there are four functions, particularly praising, expressing gratitude, compliments, and condolences. Second, the principles of politeness found are in the form of tact, agreement, wisdom, sympathy, generosity and modesty maxim. Each function contained in each type of speech act has a marker which is also a marker for politeness.
\end{abstract}

Keywords: language politeness, female politician, directive and expressive speech acts, the principle of politeness

\section{INTRODUCTION}

Social media can be used as an effective means of political communication in the process of democratic life [1]. This means that public officials - in this case members of the house of regional representatives or hereinafter DPRD- can take advantage of this media to facilitate communication with constituents or the public. As public officials, DPRD members are one component of the nation who should be role models for the community. The behavior of the officials concerned will always be in the spotlight for the community. The behavior in question can be verbal behavior (language performance) or nonverbal behavior in the form of actions. They must be able to use the Indonesian language correctly and politely, including on social media platforms.

Being able to use Indonesian correctly and politely is a necessity for politicians. As representatives of the people, they are obliged to voice the aspirations of the people in parliament. Furthermore, they are also obliged to re-inform the community about the continuity of the problem either directly (verbally) or indirectly (in writing). For this reason, the issue discussed in this paper relates to the politeness of language of political figures, especially women legislators (in DPRD) at the West Sumatra level on social media. In this paper, the discussion is limited to (1) the functions of directive and expressive speech acts, (2) the principles of politeness found in both types of speech acts.

The study of the use of language (speech acts) is an urgent matter to discuss because the results obtained can be used as input for legislative institutions. The input provided is useful on the one hand to further improve the ability to use various media, especially social media as a means of conveying messages and information to the public. On the other hand, this can also be used by the legislature as material for self-evaluation related to how they should communicate (act in speech) with the community, especially on social media.

Social media is a fairly dynamic fighting arena. There are times when these politicians benefit from social media support, at other times, it is also possible that they 
will receive criticism from fellow users on the social media. This is a social phenomenon that must be taken seriously by politicians who actively use social media. Suardi [2] emphasized that this phenomenon indicates that society has become increasingly critical, which demands that the people's representatives must be more professional, smart, and wise in conveying political messages. If not, the people who are their constituents become less sympathetic and undermine the self-image of the people's representatives themselves.

Furthermore, from the literature review that has been carried out, similar studies with the topic of this paper have repeatedly been discussed by other academics. These linkages include the object of research, particularly language used in social media (Facebook, Twitter, or Instagram); the subject discussed, that is political figures, especially members of the legislative (DPR and DPRD); and the focus discussed, precisely the types of speech acts and the principle of politeness.

Related articles regarding the use of social media have been discussed by Maulidi (2015), Susanto (2017), Fallianda (2018), Palupi and Endahati (2019). Maulidi [3] examines the politeness of language on Facebook. The result states that the form of politeness that is realized is in the form of gratitude. Susanto [4] discusses social media as a supporter of political communication networks. The results obtained show several advantages of social media because social media users are not bound by social, economic and political status. In addition, social media and mainstream mass media have different characters in spreading messages to audiences; social media is a supporter of political communication networks in state democracy. Fallianda [5] explored the politeness of language of Instagram social media users with Brown and Levinson's theory of politeness. The discussion focused on using positive politeness strategies, negative politeness strategies and vague politeness strategies. This paper also discusses the influence of social distancing variables and the level of coercion that has the greatest influence on choosing the face-saving level for Instagram users.

Furthermore, articles are directly related to the subject being discussed, namely political figures, particularly members and candidates for DPRD members including articles written by Sitorus et al. (2015), Winda (2016), Sukri and Maryam (2016). Sitorus, et al. [6] discusses the language of politeness and semiotic power from speakers of legislative candidates.

As a result, candidates for legislative members used the six maxims put forward by Leech, namely the maxims of wisdom, acceptance, generosity, humility, approval, and opportunity with different percentages. All maxims are realized in the declarative and imperative modes. Another researcher, Winda (2016) [7] examined the communication ethics of DPRD members from East Kalimantan. The result generally states that the DPR members are polite, but it does not explain what politeness being expressed. Sukri and Maryam [8] examined politeness in language, which is the principle of politeness used by DPR members in the meetings. In short, the situation and the variety of language used is the spoken language used directly. The similarities of these three studies are the research subjects, which both examine the politeness of the language of legislative officials or members of DPR/DPRD.

A number of articles related to the focus of the discussion were found including those written by Tatang and Syihabuddin (2014), Chamamah and Turahmat (2016), Syah (2017), Ekawati, Mursia (2017), Murti, et al.(2018), Kurniati, et al.(2018), and Defina (2018). The focus of the discussion in this article can also be divided into three groups. There are writings that focus only on directive or expressive speech acts and some others also discuss both. Here is the explanation.

Tatang and Syihabuddin [9] discussed the types of directive speech acts in the book Al'arabiyah Bayna Yadayka, as well as the cultural values contained therein. The types of directive speech found were questions, requests, requests, offers, rejections and prohibitions. Apart from that, the directive utterances also contain the traditions and values of Arabic and Islamic culture. Syah [10] examined the politeness of directive speech acts in the Talk Show "Satu Jam Lebih Dekat" on TV One channel. The result, found six sub-directive speech acts and four politeness strategies consisting of direct, positive, negative and indirect strategies. The politeness strategy of the directive speech acts used supports the effectiveness of the communication in the Talk Show especially in terms of affective, cognitive, and conative.

Furthermore, Chamamah and Turahmat [11] discussed expressive speech acts in the form of flattering, praising, saying thank you, criticizing, complaining, blaming, and saying congratulations which were written on the walls of the truck. Ekawati [12] examined pseudo politeness in expressive speech acts. The results obtained were specifically about the expression of anger as a form of expressive speech acts. Anger can be addressed to a speech partner (second person) or third person. Anger directed at the third person is called by the author with pseudo politeness and can be expressed directly or indirectly. The similarity of this paper with this article is that they both examine expressive speech acts, but the focus of the study is very different.

In another study, Defina [13] discussed the types of expressive illocutionary speech acts that children spoke while playing football. The results found expressive speech acts in the form of blaming, apologizing, congratulating, praising, condoling, welcoming, criticizing, complaining, and flattering. Murti, et al. [14] wrote an article about expressive speech acts in the film "Kehormatan dibalik Kerudung" directed by Tya Subiakto Satrio. The results are expressive speech acts in the form of praise, thanks, apologies, happiness, and complaining. Kurniati, et al., [15] examined the directive and expressive speech acts with the object of study, namely the dialogue in the film "Surga yang tak Dirindukan". The results obtained for the most dominant directive speech act were question directive speech acts with a questioning function. Then, the dominant form of expressive speech act is greeting speech. This means that the point of view of this 
research is not the same as the study that is currently being discussed.

From the literature review above, it can be stated that the writing being discussed is not exactly the same as the studies that have been written by previous researchers.

\section{METHODOLOGY}

This type of research is a qualitative-descriptive study. This type of qualitative research is considered suitable in assessing and describing the performance and politeness of public official communications, in this case DPRD members. The data of this research are utterances containing information and written messages of women DPRD members of West Sumatra when communicating with the community. The data source is the social media account (Facebook, Twitter or Instagram) of these political figures.

Furthermore, the methods and data collection techniques used are observation methods with basic techniques and advanced techniques. The basic technique in question is the tapping technique with advanced techniques namely listening not-participant in conversation and recording technique. The results of the recording technique are continued with the technique of recording and inventory using the prepared format. Inventory data are re-selected continually until the selected data (corpus) is obtained, and this selected data is analyzed.

Data analysis activities are implemented through several stages. First, data that has been inventoried in tabular form are then grouped according to problems and objectives. Second, the grouped data were analyzed based on pragmatic theory, particularly speech act theory and language politeness. Third, the data that has been analyzed are then interpreted and discussed based on theory and compared with relevant studies and concluded.

\section{RESULT AND DISCUSSION}

The explanation in this section is about the results of data analysis on language politeness in directive and expressive speech acts spoken by women members of the West Sumatra DPRD. Before heading to the session on describing the politeness of language, it is first explained about the functions of the two types of directive and expressive speech acts. After that, politeness was described. The theory used is based on the opinion of Leech [18]; Syahrul [19]; Chaer [20]; Yule [21]; Eelen [22]; Cummings [23]; and Wijana [24].

\subsection{Function of Directive Speech Acts}

Conceptually, the directive speech act is a speech act that directs the speech partner to do something in accordance with what is contained in the speech spoken by the speaker. In this paper, 80 directive speech acts are analyzed which can be grouped based on their function. The three functions in question can be observed in table 1 below.
Table 1. Function in directive speech acts

\begin{tabular}{|l|l|r|r|}
\hline No. & \multicolumn{1}{|c|}{ Function indicated } & Sum & \multicolumn{1}{c|}{$\%$} \\
\hline 1 & Encourage/urge & 20 & 25,0 \\
\hline 2 & Request & 42 & 52,5 \\
\hline 3 & Alert & 18 & 22,5 \\
\hline \multicolumn{2}{r|}{ total } & 80 & 100,0 \\
\hline
\end{tabular}

From table 1 above, it can be further explained that there are three functions of directive speech acts, among others, inviting/suggesting function, appealing function, and the reminding function. Each function is marked by a specific marker. The following descriptions will explain these matters one by one.

\subsubsection{Encourage/Urge}

Conceptually, directive speech act which functions to encourage/urge, it can be explained that the speakers suggest or encourage speech partners to do something. The directive speech acts with the inviting function is indicated by several markers, including the exclamation words "mari" and "ayo", verbs with suffix $-i$ and -kan. The diction for "mari" and "ayo" in the interjection category means to invite as the marker to smooth the speech because the directive speech act basically contains purpose of command.

This means that the speaker through the speech wants her speech partner to do or not do something in accordance with what is contained in the speech. The words mari and ayo can access sentences that have "verb" predicate (base and derivative). For predicates with derivative verbs, namely verbs with suffix $-i$ and $-k a n$ which morphologically (grammatically) is a verb which means an act of command (imperative). In addition, we also found the interjection of "mari bergabung" with the particle affirmation verb, e.g. -lah. Examples of data for this category are as follows.

1) Mari kita bergandeng tangan untuk sama-sama melewati masa-masa sulit ini. (KAD/61/140) Let's join hands together to get through this difficult time

2) Mari kita kurangi aktivitas di luar ruangan. (WD/FB/72/187)

Let's limit outdoor activities

3) Ayo timbang balita dengan ceria. (YE/47/92)

Come on, weigh the toddler cheerfully

4) Lebarkan senyummu, terangkan jiwamu tebarkan kebaikan, (WD/FB/79/214)

Broaden your smile, brighten your soul and spread kindness

5) Jadilah wanita yg menegarkan banyak orang karena masih banyak kekuatan tersembunyi di luar kekuatan wanita yang terlihat. By. Uni Wulan (WD/FB/70/181) Be a woman who upholds many people because there are still many hidden powers beyond the visible strength of women. By. Uni Wulan 


\subsubsection{Request}

The directive speech act with the function of requesting is characterized by the use of the adverb "semoga/hopefully" which generally begins the speech. The directive speech act with a request function is indicated by the use of the adverb "semoga"/hopefully which generally begins the speech. The adverbs "semoga"/hopefully is synonymous with "mudahmudahan"/god willing and "mohon/please" with the meaning of ask/beg, hopelexpect. This means, a speech beginning with the adverb "semoga"/hopefully means 'to demand' and 'to expect'. There are also predicates with marker VD + -lah, VD + -kan. An example for this function can be seen in the following data.

6) Semoga di usia 16 tahun ini, Kabupaten Pasaman Barat bisa lebih baik lagi.(YS/37/67)

Hopefully, at the age of 16, West Pasaman Regency will be even better.

7) Semoga menjadi keluarga Sakinawah Mawaddah Warrahmah. (WD/FB/90/248)

Hopefully it will be the Sakinawah Mawaddah

Warrahmah family.

8) Kuatkanlah kami ya ALLAH Aamiin yra. (ET/119/327)

Strengthen us, O ALLAH Aamiin yra.

9) Mohon Maaf Lahir dan Bathin. (YS/39/72)

Forgive me, my body and soul

10) Mudah2an komunikasi dapat terjaga dengan baik, dan saling bertukar informasi.. barrakallahu. (WD/FB/93/253)

Hopefully communication can be maintained properly, and exchange information .. barrakallahu.

\subsubsection{Alert}

The directive action with the function of reminding/prohibiting begins with the use of the adverb "jangan"/do not which means alerting. In addition, directive speech acts to remind/prohibit are also marked by the use of basic verbs, basic verbs + -kan. This can be observed in the following data.

11) Jangan terlambat, ambil sikap. (WD/FB/94/260) Don't be late, take a stand.

12) Cegah Covid 19. (YS/38/70) Prevent Covid 19.

13) Jaga jarak, wajib bermasker. (IM/49/97) Keep up your distance, you must wear a mask.

14) Pastikan Anda Terdaftar sebagai Pemilih. (YS/17/29)

Make sure you are registered as a voter.

15) Selamatkan keluarga, dengan tetap berada di rumah. (WD/FB/94/261)

Save the family, by staying at home.

\subsection{Function of Expressive Speech Acts}

Essentially, expressive speech acts are speech acts that are used to express psychological and evaluative conditions of speaker. There were 59 expressive speech actions analyzed. All of these utterances can be grouped into four functions, which can be seen in table 2 below.

Table 2. Function in expressive speech acts

\begin{tabular}{|c|l|r|r|}
\hline No. & \multicolumn{1}{|c|}{ Function indicated } & \multicolumn{1}{c|}{ Sum } & \multicolumn{1}{c|}{$\%$} \\
\hline 1 & praising/being grateful & 14 & 23,7 \\
\hline 2 & showing gratitude & 35 & 59,3 \\
\hline 3 & appreciating & 8 & 13,6 \\
\hline 4 & condolences & 2 & 3,4 \\
\hline \multicolumn{2}{r}{ total } & 59 & 100,0 \\
\hline
\end{tabular}

From table 2 it can be explained that the functions of expressive speech acts include praising/being grateful, showing gratitude, appreciating and condolences. The four functions will be explained in the following description.

\subsubsection{Praising/being grateful}

Expressive speech acts with the function of praising/being grateful is a manifestation of the speaker's psychological and evaluative condition. In this context, these psychological and evaluative conditions are realized in the form of praise and gratitude. Expressive speech acts with this function are indicated by the use of the expression 'Alhamdulillah'. The data on expressive speech acts to praise this function can be seen in the following data.

16) Alhamdulillah, hari ini kita berada di Kenagarian Katiagan Mandiangin. (YS/1/1)

Alhamdulillah, today we are in Kenagarian Katiagan Mandiangin.

17) Ahamdulillah, hari ini berkesempatan hadir dalam acara kitanan di Sialang. (YS/6/13)

Ahamdulillah, today had the opportunity to attend the circumcision ceremony in Sialang.

18) Melalui dana Pokir Dewan 2020, satu persatu PR mulai dicicil untuk memenuhi permintaan masyarakat, Alhamdulillah. (IM/60/106) Through the Pokir Dewan 2020 funding, little by little homework has started to be done, to meet community demand, Alhamdulillah.

19) Alhamdulillah, kegiatan DPC Pendidikan Politik Partai Gerindra, Senin, 30/12-19 selesai dilaksanakan. (WD/FB/78/205)

Alhamdulillah, the Political Education DPC activity from the Gerindra Party, Monday, 30/12-19 was completed.

20) Alhamdulillah, aksi Demonstrasi Aliansi Mahasiswa Paliko, berjalan tertib dan damai. (WD/95/261)

Alhamdulillah, the Paliko Student Alliance Demonstration action went orderly and peacefully.

\subsubsection{Showing gratitude}

Expressive speech act with compliment function comes with a congratulation marker. This means that the speech act begins with an expression of congratulations, as shown in the following data.

21) Selamat Menunaikan Ibadah Puasa $1441 \mathrm{H}$.

(YS/39/71)

Happy Fasting $1441 \mathrm{H}$. 
22) Selamat Menempuh Hidup baru Wulan. (WD/68/155)

Get a Happy New Life Wulan

23) Selamat milad kakak ku tercinta (Any Thrisna), wanita hebat, tegar, dan tdk pernah mengeluh.. (FN/112/311)

Happy birthday to my beloved sister (Any Thrisna), a great woman, tough, and never complains

24) Happy wedding Thresya dan Raka (WD/FB/82/222) Happy wedding Thresya and Raka

25) Dirgahayu 12 Partai Gerindra (WD/FB/83/224) Dirgahayu 12th Gerindra Party

There is another expression in expressive speech acts which has the same meaning as 'congratulation'. This is revealed in data (24) through expressions such as Happy Wedding and (25) Dirgahayu.

\subsubsection{Appreciating}

Expressive speech acts with appreciating function begins with an expression such as "terima kasih"/thank you. This can be seen in the following sample data.

26) Terima kasih atas kiriman fotonya sahabat masa kecil, miss u (IM/53/101)

Thank you for the photo submission, childhood friend, miss u

27) Terimakasih pd panitia, alhamdulillah acara lancar dan luar biasa.... (WD/FB/78/208)

Thank you to the committee, thank God, the program went well and was extraordinary ....

28) "Terimakasih atas kepercayaan dari masyarakat kepada Partai Gerindra" (WD/FB/83/226)

"Thank you for the trust of the public in the Gerindra Party".

29) Terima Kasih atas silaturahmi yang terjalin dengan baik selama ini. (FN/111/309)

Thank you for the good relationship so far.

30) Terima kasih atas atensi teman 2 FB semua (ET/116/320)

Thank you for your attention from all 2 FB friends.

Based on five examples of expressive speech acts data with the appreciating function, it can also be seen that data also functions as an act of praise, namely data on sequence number 27.

\subsubsection{Condolence}

The data for condolence expression is very limited, which only two data. Despite that, the data description is still displayed.

31) Turut berduka atas musibah yang menimpa sahabat paramedis RSUD Kota Padang Panjang. (KAD/65/142)

Grieve over the tragedy that befell a paramedic friend of the Padang Panjang City Hospital
32) Innalillahiwainnaillaihirojiun... Telah berpulang kerahmatullah Sahabat Kita (teman SMA), M. Hafis di Palembang..(WD/FB/93/254)

Innalillahiwainnaillaihirojiun... Has returned to the side of God, Our Friend (high school friend), M. Hafis in Palembang

\subsection{Language Politeness}

The focus of the discussion in this section is on the principles of language politeness found in directive and expressive speech acts. From the results of data analysis, the following conclusions are obtained. In general, the directive and expressive speech acts used by women DPRD members of West Sumatra on social media are categorized as "polite" because they fulfill the principle of politeness in the form of maxims stated by Leech (1993). The data that shows this politeness can be more examined in the following explanation.

\subsubsection{The approbation maxim}

Theoretically, this approbation maxim can be interpreted as the speaker should avoid things that are displeasing to the speech partner. If this is fulfilled by the speakers, the speech is considered polite. This approbation maxim is found in the types of expressive speech as shown in the following sample data.

33) Kami memberikan apresiasi atas kesadaran masyarakat kota Padang Panjang dalam mengantisipasi penyebaran virus ini. (KAD/63/128) We appreciate the awareness of the people of Padang Panjang in anticipating the spread of this virus.

34) Alhamdulillah masyarakat kita sudah paham, bahwa kasus ini perlu kerjasama antara masyarakat dg pemerintah, (WD/100/280)

Alhamdulillah, our people already understand that this case requires collaboration between the community and the government.

35) Selamat dan Sukses Pelantikan Anggota DPRD Provinsi Sumbar, Terkhusus utk Perwakilan dr Partai Gerindra. (WD/68/ 156)

Congratulations and Success in the Inauguration of Members of the West Sumatra Provincial DPRD, especially for the representatives of the Gerindra Party.

36) Selamat milad kakak ku tercinta (Any Thrisna), wanita hebat, tegar, dan tdk pernah mengeluh.. (FN/112/311)

Happy birthday to my beloved brother (Any Thrisna), a great woman, tough, and never complains

37) Terima Kasih kepada Pak Ihsan Kacab BSM Pariaman beserta jajarannya sudah membantu masyarakat Kota Pariaman. (FN/110/306)

Thank you to Mr. Ihsan, Head of BSM Pariaman branch and his staff for helping the people of Pariaman city. 


\subsubsection{The agreement maxim}

The agreement maxim is also known as the appropriate maxim. In this agreement maxim, speakers and speech partners build an agreement (compatibility) and the speaker tries to minimize the mismatch. In the two types of speech acts discussed, the maxims of this agreement are found in directive speech acts as seen in the following data.

38) Mari berkunjung ke Pasaman Barat ((YS/1/4) Let's visit West Pasaman.

39) Mari hidup sehat dan Berpikir Cerdas. (YS/3/10) Let's live healthy and think smart.

40) Mari kita bergandeng tangan untuk sama-sama melewati masamasa sulit ini. (KAD/61/140) Let's join hands together to go through this difficult period.

41) Marilah tingkatkan kebersamaan dan silaturrahmi, kembali rajut persaudaraan. (WD/68/174)

Let's improve our togetherness and friendship, we will knit the threads of brotherhood again.

42) Mari kita kurangi aktivitas diluar ruangan. (WD/FB/72/187)

Let's reduce outdoor activities ..

\subsubsection{The tact maxim}

The tact maxim is a maxim that requires speaker to maximize profits for others and minimize harm for others. This maxim is also called the maxim of wisdom. The following data is an example of the principle of politeness in the form of tact maxim.

43) Semoga di usia 16 tahun ini, Kabupaten Pasaman Barat bisa lebih baik lagi.(YS/37/67)

Hopefully, at the age of 16, West Pasaman Regency will be even better.

44) Semoga pertemuan selanjutnya lebih banyak teman angkatan 2003, yg bergabung.. (WD/68/172)

Hopefully, in the next meeting there will be more friends from class of 2003, who can join ..

45) Semoga terus menebar kebaikan buat Kota Payakumbuh (WD/FB/73/190)

Hopefully it continues to spread goodness for Payakumbuh City

46) Semoga harapan kita bersama didengar dan ditindaklanjuti demi Indonesia lebih baik.. (WD/95/262)

Hopefully our common hope is heard and followed up for a better Indonesia ..

\subsubsection{The sympathy maxim}

In this sympathy maxim, there is a rule that speech participants (speakers and speech partners) must maximize sympathy between the two parties). Speech that meets this rule is categorized as polite, as can be seen in the following data.

47) Turut berduka atas musibah yang menimpa sahabat paramedis RSUD Kota Padang Panjang. (KAD/65/142)
Grieve over the tragedy that befell a paramedic friend of the Padang Panjang City Hospital

48) Innalillahiwainnaillaihirojiun... Telah berpulang kerahmatullah Sahabat Kita (teman SMA), M. Hafis di Palembang..(WD/FB/93/254)

Innalillahiwainnaillaihirojiun... Has returned to the side of God, Our Friend (high school friend), M. Hafis in Palembang

49) Semoga Allah mengampuni kesalahan beliau, dan di diterima semua Amal Ibadah. (WD/FB/93/255)

May Allah forgive his mistakes, and be accepted by all deeds and worship.

50) Semoga Teteeen, istri beliau Riza Apteni beserta keluarga besar diberikan kesabaran dan kekuatan, aamiin YRA..(WD/FB/93/256)

Hopefully Teteeen, wife of Riza Apteni and their extended family will be given patience and strength, aamiin YRA ..

51) Semoga selalu diberikan kesehatan dan kesempatan berbuat baik dihadapan Nya. (WD/98/274)

May we always be given health and the opportunity to do good in His presence.

\subsubsection{The generosity maxim}

A speech will be categorized as polite if the speaker tries to maximize respect for others, and minimize disrespect for others. This means that the speech contains a maxim of generosity. The following data are examples of utterances containing generosity maxim.

52) Kami Sekeluarga Mengucapkan Selamat Hari Raya Idul Adha 1440 Hijriah. (YS/32/55)

We as a family wish you a Happy Eid al-Adha 1440 Hijriah.

53) Selamat melanjutkan amanah pak Yulius Kaisar sbg Wakil Ketua DPRD Dari Partai Gerindra. (WD/FB/74/192)

Congratulations on continuing the mandate of $\mathrm{Mr}$. Yulius Kaisar as Deputy Chairman of the DPRD from the Gerindra Party.

54) Selamat Baminantu Bupati 50 Kota .. Bpk Irfendi Arbi, (WD/FB/76/196)

Congratulations on getting a son-in-law to the Regent of 50 Cities .. Bpk Irfendi Arbi

55) Selamat bertugas di tempat yang baru kepada Bapak AKBP Andry Kurniawan S.IK M.Hum.

(FN/111/308)

Congratulations on serving in a new place to $\mathrm{Mr}$. AKBP Andry Kurniawan S.IK M.Hum.

56) Terima kasih atas kiriman fotonya sahabat masa kecil, miss u (IM/53/101)

Thank you for the photo submission, childhood friend, miss $u$

\subsubsection{The modesty maxim}

The modesty maxim differs from the generosity maxim because the orientation of the two maxims is different. If the maxim of generosity is oriented more towards other people (speech partners), the maxim of 
modesty is oriented towards the speaker. In the maxims of modesty, speakers try to maximize respect for others (speech partners), and minimize disrespect for others. If a speech fulfills this maxim rule (fulfills the principle of politeness), the speech is categorized as polite. The following data are examples of polite speeches that fulfill the maxims of modesty.

57) Alhamdulillah hari ini kita berada di Kenagarian Katiagan Mandiangin. (YS/1/1)

Alhamdulillah, today we are in Kenagarian Katiagan Mandiangin.

58) Alhamdulillah hari ini, berkesempatan hadir dalam acara kitanan di Sialang. (YS/6/13)

59) Ahamdulillah, today had the opportunity to attend the circumcision ceremony in Sialang.

60) Mohon doa Restu dan Terimakasih Kepada masyarakat Pasaman Barat dan Pasaman. (YS/34/62) Prayers and blessings for us and thanks to the people of West Pasaman and Pasaman.

61) Semoga bahagia dan samawa yaaa. (WD/FB/82/223) We wish you happiness and sakinah, mawaddah and rahmah.

62) Semoga menjadi keluarga Sakinawah Mawaddah Warrahmah.. WD/FB/90/248)

Hopefully later it will become the Sakinawah Mawaddah Warrahmah family .

The six principles of politeness in the form of maxims are found to vary in the two types of speech acts (directive and expressive) which are the focus of the analysis. The maxim of approbation is dominant in expressive speech acts. Meanwhile, the agreement and tact maxim appears most frequently in directive speech acts. Maxim of sympathy, generosity, and modesty are found in both types of speech acts (directive and expressive). This is one of the differences between these studies and related research.

Although there are writings that both discuss directive and expressive speech acts as done by Kurniati, et. al.[15], however the object and focus under study are quite different. Kurniati, et. al. discuss directive and expressive speech acts in dialogue texts in films, and the results obtained determine the dominant speech act. Meanwhile, in addition to discussing the functions of the two speech acts, this paper also discusses the issue of language politeness. Meanwhile, in addition to discussing the functions of the two speech acts, this paper also discusses the issue of language politeness. This is also the same as the paper mentioned in the introduction.

\section{CONCLUSION}

In this article, two things are discussed, namely the function and politeness of language in directive and expressive speech acts of women members of the DPRD of West Sumatra in communicating on social media. There are three functions of directive speech acts, such as the function of inviting/suggesting, requesting, and warning. Furthermore, four functions of expressive speech acts were found including praising/giving thanks, gratitude, saying congratulations, and condolences. For the second problem regarding language politeness in directive and expressive speech acts which are analyzed based on the principle of Leech's politeness, there are six maxims, e.g. approbation, agreement, sympathy, tact, modesty, and generosity. Some of these maxims are found to be balanced in the two types of speech acts above, and some are dominant in just one type of speech act (directive or expressive).

This paper certainly has limitations. Therefore, it is suggested for researchers who share an interest in this topic, in order to express the types, functions, and politeness levels of other speech acts which can be done using the same theory, or it could be the theory of different experts.

\section{ACKNOWLEDGMENT}

This article is one of the outputs of fundamental research entitled "Performance of Language and Politeness of Indonesian Women DPR Members on Social Media", which is funded by DIPA-UNP number 023.17.2.677514/2020, dated 27

December 2019.

\section{REFERENCES}

[1] Budiyono. 2016. "Media Sosial dan Komunikasi Politik: Media Sosial sebagai Komunikasi Politik Menjelang PILKADA DKI JAKARTA 2017”. Jurnal Komunikasi Volume 11, Nomor 1, Oktober 2016.

[2] Suardi. 2016. "Antara Media Sosial dalam Komunikasi Politik”. Jurnal RISALAH, Vol. 27, No. 2, Desember 2016: $82-86$

[3] Maulidi, Ahmadi. 2015. "Kesantunan Berbahasa pada media Jejaring Sosial Facebook" e-Jurnal Bahasantodea, Volume 3 Nomor 4, Oktober 2015 hlm 42-49

[4] Susanto, Eko Harry. 2017. "Media Sosial sebagai Pendukung Jaringan Komunikasi Politik" dalam Jurnal ASPIKOM, Volume 3 Nomor 3, Juli 2017, hlm 379-398.

[5] Fallianda. 2018. "Kesantunan Berbahasa Pengguna Media Sosial Instagram: Kajian Sosiopragmatik" dalam Etnolingual Vol 2 No 1 Mei, 2018, 35-54

[6] Sitorus, Awaluddin, Nurlela dan Masdiana Lubis. 2015. Kesantunan dengan Daya Semiotika Bahasa Berkampanye Calon Legislatif Partai Golongan karya di Kabupaten Labuhan. Jurnal Kajian Linguistik, tahun ke12, no 1, Februari 2015, hal. 15-34

[7] Winda. 2016. Etika Komunikasi Anggota DPRD dalam menyampaikanAspirasi Masyarakat. (Study Di DPRD Provinsi Kalimantan Timur) e-Journal Ilmu Komunikasi Volume 4, Nomor 3, 2016 : 192-206 
[8] Sukri, Muhammad dan Siti Maryam. 2016.

"Kesantunan Berbahasa Sidang Dewan Perwakilan Rakyat Daerah: Kajian Berdasarkan Pragmatik" Prosiding Seminar Nasinal Prasasti II "Kajian pragmatik dalam Berbagai Bidang hal. 188-192

[9] Tatang dan Syihabuddin. 2014. "Analisis Tuturan Direktif dan Nilai Budaya pada Buku Al'Arabiyah Bayna Yadayka" dalam el Harakah Vol.16 No.1 Tahun 2014_111-- 129

[10] Syah, Nur Aini. 2017. "Kesantunan Tindak Tutur Direktif dalam Talk Show Satu Jam Lebih Dekat di Tv One (Tinjauan Pragmatik)" dalam Jurnal Adabiyyāt: Jurnal Bahasa dan Sastra, Vol. I, No. 1, Juni 2017, hlm. 94-111 ISSN (Online): 2549-2047, ISSN (Cetak): 25491482

[11] Chamamah, Evi dan Turahmat. 2016. "Tindak Tutur Ekspresif pada Bak Truk sebagai Alternatif Materi Ajar Pragmatik" dalam Jurnal Bahastra, Maret 2016, Volume XXXV, Nomor 2

[12] Ekawati, Mursia. 2017 "Kesantunan Semu pada Tindak Tutur Ekspresif Marah dalam Bahasa Indonesia" dalam Adabiyyāt: Jurnal Bahasa dan Sastra,Vol. I, No. 1, Juni 2017, hlm. 1-22. ISSN (Online): 2549-2047, ISSN (Cetak)

[13] Defina. 2018."Tindak Tutur Ekspresif pada AnakAnak Saat Bermain Bola di Lapangan "Ranah: Jurnal Kajian Bahasa, 7 (1), 69-85. doi: https://doi.org/ 10.26499 /rnh.v7i1.469

[14] Murti, Sri, Nur Nisai Muslihah, Intan Permata Sari. 2018 Silampari Bisa: Jurnal Penelitian Pendidikan Bahasa Indonesia, Daerah, dan Asing Vol. 1, No. 1, 2018 page 17 s.d 32

[15] Kurniati, Vivi, dkk., 2018. “Analisis Tindak Tutur Direktif dan Ekspresif pada Dialog Film Surga yang Tak Dirindukan Sutradara Kuntz Agusdan Skenario Pembelajarannya di Kelas Xi SMA" dalam Jurnal Surya Bahtera Volume 6 No 51 Maret 2018267

[16] Marlina. 2016. "Daya Tarik Facebook sebagai Media Komunikasi Alternatif". Dalam Jurnal Al-Balagh, Vol. 1, No. 1, 2016: 105-125

[17] Palupi, Muncar Tyas dan Nafisah Endahati. 2019. "Kesantunan Berbahasa di Media Sosial Online: Tinjauan Deskriptif pada Komentar Berita Politikdi Facebook" dalam Jurnal Skripta, Volume 5, No 1, Februari 201926

[18] Leech, Geoffrey. 1993. Prinsip-prinsip Pragmatik diterjemahkan oleh M.D.D Oka dari judul aslinya The Principle of Pragmatics. Penerbit Universitas Indonesia.
[19] Syahrul 2008. Pragmatik Kesantunan Berbahasa: Menyibak Fenomena Berbahasa Indonesia Guru dan Siswa. UNP Press.

[20] Chaer, Abdul. 2010. Kesantunan Berbahasa. Jakarta: Rineka Cipta.

[21] Yule, George. 2006. Pragmatik. Cetakan Pertama. Yogyakarta: Pustaka Pelajar.

[22] Eelen, Gino. 2001. Kritik Teori Kesantunan. Surabaya: Airlangga University Press.

[23] Cummings, Louise. 2007. Pragmatik: Sebuah Perspektif Multidisipliner. Yogyakarta: Pustaka Pelajar.

[24] Wijana, I Dewa Putu. 2009. Dasar-Dasar Pragmatik. Yogyakarta: Andi Yogyakarta. 